\title{
Effect of ultrasound treatment on quality and microbial load of carrot juice
}

\author{
Yu ZOU ${ }^{1 *}$, Aili JIANG ${ }^{1}$
}

\begin{abstract}
Effect of ultrasound treatment on carrot juice was investigated through measuring $\mathrm{pH}$, electrical conductivity, viscosity, visual color, total soluble solids, total sugars, total carotenoids, ascorbic acid contents and microbial load. No significant effect $(p>0.05)$ of ultrasound treatment on $\mathrm{pH}$ of carrot juice was observed. Electrical conductivity, viscosity and color values gradually increased $(p<0.05)$ with treatment time increase. Total soluble solids, total sugars, total carotenoids and ascorbic acid contents of carrot juice were significantly improved $(p<0.05)$ due to ultrasound treatment. Moreover, significant decrease $(p<0.05)$ in microbial load of sonicated carrot juice was observed. Results from present study suggested that ultrasound treatment could improve quality and safety of carrot juice.
\end{abstract}

Keywords: ultrasound treatment; carrot juice; quality; microbial load.

Practical Application: Ultrasound treatment technology can be potentially employed for juice or other food processing.

\section{Introduction}

Carrot juice is produced from carrot (Daucus carota L.), a vegetable root widely cultivated in many parts of the world (Di Giacomo \& Taglieri, 2009). Carrot juice not only contain many important dietary components such as vitamins, minerals and fiber, but also are considered as one of the richest sources of bioactive compounds that benefit human health (Demir et al., 2004). Oral intake of carrot juice also displays other beneficial physiological effects including reduced DNA damage, increased levels of antioxidants and reduced inflammation (Potter et al., 2011).

During the last few decades, research on food processing has focused on meeting consumer demands for more nutritious, healthier and safe food, with the interest moving from conventional thermal treatments towards non-thermal processing techniques (Caminiti et al., 2011). While thermal processing may cause some adverse loss in the nutritional and organoleptic attributes of food product, non-thermal technologies have the potential to improve quality and ensure safety without any adverse effect and damage to the nutrients (Gómez et al., 2011).

Ultrasound treatment is an innovative non-thermal processing technique that can effectively improve the health related quality parameters of food product (Cheok et al., 2013). In recent studies about effect of sonication on apple juice (Abid et al., 2013), kasturi lime juice (Bhat et al., 2011), cantaloupe melon juice (Fonteles et al., 2012) and orange juice (Tiwari et al., 2008), ultrasound treatment technology has been proved to a desirable method of juice processing, which can avoid losses in beneficial nutrients and reduce the microbial load in the fruit juices. It is considered to be more advantageous due to its shortened processing time with lower energy consumption (Abid et al., 2014). However, there is little information available in literature about the investigation of the effect of ultrasound treatment on carrot juice processing.

The main objective of this study was to investigate in detail the effect of ultrasound treatment on the quality of carrot juice including physicochemical parameters $(\mathrm{pH}$, electrical conductivity, viscosity, visual color, total soluble solids and total sugars) and bioactive compounds (total carotenoids and ascorbic acid). Meanwhile, microbial load of sonicated carrot juice was analyzed to evaluate the effect of ultrasound treatment on the safety of carrot juice.

\section{Materials and methods}

\subsection{Material}

Fresh carrots (grown in Dalian City and harvested in September 2014) were purchased from a local market in Dalian City (Liaoning Province, China), stored at $-20^{\circ} \mathrm{C}$ and kept at $4{ }^{\circ} \mathrm{C}$ for thaw before use. $\beta$-Carotene was purchased from Sigma-Aldrich Chemicals Co. (St. Louis, USA). Ascorbic acid was obtained from Sinopharm Chemical Regent Co., Ltd. (Shanghai, China). All other chemicals and reagents used in the experiment were of analytical grade.

\subsection{Preparation of carrot juice}

The carrots were washed with tap water to remove adhered dirt and dust particles and dried with paper towels. Then, carrots were crushed using an electrical juice extractor (BL25C46, Guangdong Midea Electric Appliances Co., Ltd., Foshan, China). Carrot juice was filtered through double layered sterilized muslin cloth to remove coarse particles and impurities from the juice. The juice sample was put into a conical flask for ultrasound treatment. 


\subsection{Ultrasound treatment of carrot juice}

Ultrasound treatment of carrot juice was performed in an ultrasound cleaning bath (KQ250-DB, Kunshan Ultrasound Instrument Co., Ltd., Suzhou, China) working at a frequency of $40 \mathrm{kHz}$ and a ultrasound intensity of $0.5 \mathrm{~W} / \mathrm{cm}^{2}$ (the internal dimensions: $300 \times 240 \times 150 \mathrm{~mm}$ ) for 20,40 or $60 \mathrm{~min}$. All the treatments were performed in darkness to avoid any interference of light with samples. For comparative purposes, an untreated juice sample was similarly retained and used as control (non-sonicated).

\subsection{Determination of $p H$}

The $\mathrm{pH}$ of sample solution was measured using a digital pH meter (FE20-FiveEasy, Mettler Toledo, Inc., Greifensee, Switzerland). Before analysis, the $\mathrm{pH}$ meter was calibrated with commercial buffer solutions of $\mathrm{pH} 7.0$ and 4.0 . Then, $50 \mathrm{~mL}$ of sample solution was placed in a $200 \mathrm{~mL}$ beaker and stirred continuously with a magnetic stirrer and $\mathrm{pH}$ was measured at $20{ }^{\circ} \mathrm{C}$.

\subsection{Determination of electrical conductivity and viscosity}

The electrical conductivity of sample solution was measured by a digital conductivity meter (FE30-FiveEasy, Mettler Toledo, Inc., Greifensee, Switzerland) at $20^{\circ} \mathrm{C}$. The viscosity of sample solution was measured at $20^{\circ} \mathrm{C}$ by using a rotary viscometer (DNJ-8S, Shanghai Jingmi Scientific Instrument Co., Ltd., Shanghai, China) with S-4 spindle at $60 \times g$.

\subsection{Determination of visual color}

Visual color of sample solution was measured using a Minolta colorimeter (CR-400, Minolta Camera Co., Ltd., Osaka, Japan) with the Hunter Lab color system. The color values were expressed as $L^{*}$ (whiteness or brightness/darkness), $a^{*}$ (redness/greenness) and $b^{\star}$ (yellowness/blueness).

\subsection{Determination of total soluble solids}

Total soluble solids were measured as ${ }^{\circ}$ Brix at $20{ }^{\circ} \mathrm{C}$ using a hand held refractometer (Master-20M, ATAGO Co., Ltd., Tokyo, Japan).

\subsection{Determination of total sugars}

Total sugars were measured with phenol-sulfuric acid method (Cuesta et al., 2003). The sample solution $(0.6 \mathrm{~mL})$ and the phenol solution $(0.3 \mathrm{~mL})$ were added to screw cap tubes, which were capped and vortex-stirred. Then $1.5 \mathrm{~mL}$ of concentrated sulfuric acid was added directly against the liquid surface in $10 \mathrm{~s}$. The tube was then closed, vortex-stirred for $5 \mathrm{~s}$ and incubated for $30 \mathrm{~min}$ at $20^{\circ} \mathrm{C}$. The absorbance was measured at $490 \mathrm{~nm}$ using distilled water as blank in a UV-2802 diode array spectrophotometer (Unico Instrument Co., Ltd., Princeton, USA).

\subsection{Determination of total carotenoids}

Total carotenoids were measured by the method of Liao et al. (2007) with slight modifications. The sample solution $(25 \mathrm{~mL})$ was taken in a separation funnel and then $80 \mathrm{~mL}$ of $n$-hexane/acetone $(1: 1, \mathrm{v} / \mathrm{v})$ was added in it, shook well and held for $5 \mathrm{~min}$. After separation, organic phase was extracted. Aqueous phase was repeatedly extracted by using $15 \mathrm{~mL}$ of $n$-hexane/acetone (1:1, v/v) until it became colorless. The organic phase was dehydrated by adding anhydrous sodium sulfate in it. Total carotenoids were determined at $450 \mathrm{~nm}$ by using a UV-2802 diode array spectrophotometer. A suitable calibration curve was prepared using standard solution of $\beta$-carotene and the results were expressed as $\mathrm{mg} / \mathrm{L}$ of carrot juice.

\subsection{Determination of ascorbic acid}

The content of ascorbic acid was measured according to the method reported by Lee \& Coates (1999) with slight modifications. An Agilent 1200 HPLC (Agilent Technologies Co., Santa Clara, USA) with a SB-C18 column $(4.6 \times 250 \mathrm{~mm})$ was used. The mobile phase was $30 \%(\mathrm{v} / \mathrm{v})$ methanol in distilled water with a flow rate of $1.0 \mathrm{~mL} / \mathrm{min}$. The detector was set at $280 \mathrm{~nm}$. Before analysis, the sample solution was filtered by using $0.45 \mu \mathrm{m}$ diameter syringe filter, and the injection volume was $20 \mu \mathrm{L}$. A suitable calibration curve was prepared using standard solution of ascorbic acid and the results were expressed as $\mathrm{mg} / \mathrm{L}$ of carrot juice.

\subsection{Microbial analysis}

Microbial analysis of control and treated juice samples were performed by the method previously reported by Abid et al. (2013) with a minor modification. Total plate count was determined by pour plate method. Sterilized distilled water was used to make serial dilutions which were poured into sterile petri plates. Molten agar $(15 \mathrm{~mL})$ was added to each petri dish and then the petri dishes were allowed to set at $25^{\circ} \mathrm{C}$ for $30 \mathrm{~min}$. The dishes were shifted to an incubator (DNP-9052, Shanghai Jinghong Laboratory Apparatus Co., Ltd, Shanghai, China) at $37^{\circ} \mathrm{C}$ for $1 \mathrm{~d}$ by turning the dishes upside down. Colonies in juice samples were counted by multiplying with reciprocal. The results were expressed as log colony-forming units $(\mathrm{CFU} / \mathrm{mL})$ of sample. Pour plate method was also used to determine the total yeast and mold counts. Potato dextrose agar (PDA) powder was dissolved in distilled water to prepare media. All the petri dishes containing PDA were placed in an incubator at $30^{\circ} \mathrm{C}$ for $3 \mathrm{~d}$. The yeast and mold were counted in each petri dish and the results were shown as $\mathrm{CFU} / \mathrm{mL}$ of juice.

\subsection{Statistical analysis}

The experimental results obtained were expressed as means $\pm \mathrm{SD}$ of triplicates. Differences among means were evaluated using Fisher's F-test at a significance level of $p<0.05$.

\section{Results and discussion}

\subsection{Effect of ultrasound treatment on $\mathrm{pH}$ and electrical conductivity}

It was obvious from the result that there was no significant change $(p>0.05)$ in $\mathrm{pH}$ of carrot juice during ultrasound treatment (Table 1). In a similar study, Bhat et al. (2011) also found that ultrasound treatment did not give significant influence $(p>0.05)$ 
on $\mathrm{pH}$ of kasturi lime juice in all the treatments. Meanwhile, the slight increase was observed in electrical conductivity of sonicated carrot juice compared to control as shown in Table 1. In general, liquid foods are electrically conductors due to the presence of nutrients, such as minerals, vitamins and proteins (Abid et al., 2014). At present study, this slight increase in electrical conductivity might be attributed to the release of mineral elements or vitamin came from carrot tissues. Ultrasound treatment could facilitate the release of these compounds when they were entrapped into vegetal cells or colloidal particles.

\subsection{Effect of ultrasound treatment on viscosity}

There was a significant increase $(p<0.05)$ in viscosity of carrot juice sonicated for 20,40 and $60 \mathrm{~min}$ as compared to non-sonicated juice sample (Table 1). This result was similar to those previously reported by Wu et al. (2008). Their studies showed that the viscosity of tomato juice also significantly increased after ultrasound treatment. This phenomenon might be attributed to ultrasound treatment that caused more molecules, particularly sugars compounds, to permeate cell membranes and increase their concentration in the colloidal system (SuárezJacobo et al., 2011). The viscosity was correlated to the sugar concentration and thus the release of sugar compounds made the juice more viscous.

\subsection{Effect of ultrasound treatment on visual color}

The result of the color measurement is shown in Table 2. Visual color of carrot juice was significantly influenced $(p<0.05)$ by ultrasound treatment. $L^{*}, a^{*}$ and $b^{*}$ values gradually increased with treatment time increase. Tiwari et al. (2008) studied the visual color of sonicated orange juice and found that the color values changed with treatment time increase. In particular, a sharp increase of the $b^{*}$ value was reported when orange juice was treated with ultrasound for $10 \mathrm{~min}$, which is similar to the results obtained in the present study. This variation of visual color was possibly connected with change in light absorption of pigments such as carotenoids, which might be influenced during ultrasound treatment.

\subsection{Effect of ultrasound treatment on total soluble solids and total sugars contents}

Total soluble solids and total sugars are major quality parameters of carrot juice which affect the sensory characteristics of juice. The result showed that ultrasound treatment caused significant change $(p<0.05)$ in total soluble solids and total sugars between non-sonicated and sonicated juice samples (Table 3). Total soluble solids increased from 4.04 to $4.19^{\circ} \mathrm{Brix}$ and total sugars increased from 14.42 to $14.82 \mathrm{~g} / \mathrm{L}$, respectively. This result regarding the enhancement of total soluble solids

Table 1. Effect of ultrasound treatment on $\mathrm{pH}$, electrical conductivity and viscosity of carrot juice.

\begin{tabular}{cccc}
\hline $\begin{array}{c}\text { Treatment time } \\
(\mathrm{min})\end{array}$ & $\mathrm{pH}$ & $\begin{array}{c}\text { Electrical conductivity } \\
(\mathrm{ms} / \mathrm{cm})\end{array}$ & $\begin{array}{c}\text { Viscosity } \\
(\mathrm{cP})\end{array}$ \\
\hline 0 & $5.22 \pm 0.03^{\mathrm{a}}$ & $9.88 \pm 0.05^{\mathrm{b}}$ & $1.97 \pm 0.05^{\mathrm{c}}$ \\
20 & $5.21 \pm 0.04^{\mathrm{a}}$ & $9.91 \pm 0.04^{\mathrm{b}}$ & $2.06 \pm 0.04^{\mathrm{b}}$ \\
40 & $5.23 \pm 0.02^{\mathrm{a}}$ & $9.98 \pm 0.06^{\mathrm{ab}}$ & $2.18 \pm 0.07^{\mathrm{a}}$ \\
60 & $5.25 \pm 0.03^{\mathrm{a}}$ & $10.06 \pm 0.07^{\mathrm{a}}$ & $2.23 \pm 0.08^{\mathrm{a}}$ \\
\hline
\end{tabular}

Values with different letters in the same column are significantly different $(p<0.05)$.

Table 2. Effect of ultrasound treatment on visual color of carrot juice.

\begin{tabular}{cccc}
\hline $\begin{array}{c}\text { Treatment time } \\
(\min )\end{array}$ & \multicolumn{3}{c}{ Visual color } \\
\cline { 2 - 4 } & $L^{*}$ & $a^{*}$ & $b^{*}$ \\
20 & $32.86 \pm 0.06^{\mathrm{c}}$ & $3.94 \pm 0.05^{\mathrm{b}}$ & $6.87 \pm 0.04^{\mathrm{d}}$ \\
40 & $33.02 \pm 0.05^{\mathrm{b}}$ & $3.99 \pm 0.05^{\mathrm{b}}$ & $6.98 \pm 0.03^{\mathrm{c}}$ \\
60 & $33.14 \pm 0.03^{\mathrm{a}}$ & $4.08 \pm 0.03^{\mathrm{a}}$ & $7.09 \pm 0.06^{\mathrm{b}}$ \\
\hline
\end{tabular}

Values with different letters in the same column are significantly different $(p<0.05)$.

Table 3. Effect of ultrasound treatment on total soluble solids, total sugars, total carotenoids and ascorbic acid contents of carrot juice.

\begin{tabular}{ccccc}
\hline $\begin{array}{c}\text { Treatment time } \\
(\mathrm{min})\end{array}$ & $\begin{array}{c}\text { Total soluble solids } \\
\left({ }^{\circ} \text { Brix }\right)\end{array}$ & $\begin{array}{c}\text { Total sugars } \\
(\mathrm{g} / \mathrm{L})\end{array}$ & $\begin{array}{c}\text { Total carotenoids } \\
(\mathrm{mg} / \mathrm{L})\end{array}$ & $\begin{array}{c}\text { Ascorbic acid } \\
(\mathrm{mg} / \mathrm{L})\end{array}$ \\
\hline 0 & $4.04 \pm 0.05^{\mathrm{b}}$ & $14.42 \pm 0.12^{\mathrm{b}}$ & $3.47 \pm 0.12^{\mathrm{c}}$ & $5.26 \pm 0.10^{\mathrm{c}}$ \\
20 & $4.09 \pm 0.06^{\mathrm{ab}}$ & $14.58 \pm 0.11^{\mathrm{b}}$ & $3.68 \pm 0.07^{\mathrm{b}}$ & $5.45 \pm 0.08^{\mathrm{b}}$ \\
40 & $4.12 \pm 0.05^{\mathrm{ab}}$ & $14.79 \pm 0.09^{\mathrm{a}}$ & $3.89 \pm 0.13^{\mathrm{a}}$ & $5.69 \pm 0.14^{\mathrm{a}}$ \\
60 & $4.19 \pm 0.07^{\mathrm{a}}$ & $14.82 \pm 0.14^{\mathrm{a}}$ & $3.94 \pm 0.14^{\mathrm{a}}$ & $5.67 \pm 0.12^{\mathrm{a}}$ \\
\hline
\end{tabular}

Values with different letters in the same column are significantly different $(p<0.05)$. 
and total sugars in sonicated carrot juice was in agreement with the previous study of Fonteles et al. (2012) who reported improvement of these two parameters in cantaloupe melon juice after ultrasound treatment. The increase of total soluble solids and total sugars might be ascribed to the increase in extraction efficacy by ultrasound treatment, causing destruction of plant tissues and cell walls (Zou et al., 2010). It resulted in more water could enter cells and the more soluble solids could permeate cell membranes.

\subsection{Effect of ultrasound treatment on total carotenoids and ascorbic acid contents}

Carotenoids and ascorbic acid are present in considerable amounts in carrot juice products and are known to be the major cause of their antioxidant capacity and also contribute to their sensory properties (Wang et al., 2006). In addition, the color of carotenoids can increase the esthetic value of juice products and make it more attractive for consumption. The effect of ultrasound treatment on total carotenoids and ascorbic acid contents of carrot juice is shown in Table 3. Result of present study indicated a significant increase $(p<0.05)$ in total carotenoids and ascorbic acid contents in the sample sonicated for $40 \mathrm{~min}$ compared to sample sonicated for $20 \mathrm{~min}$ and control (non-sonicated) sample. Similarly, Abid et al. (2013) reported that ultrasound treatment increased ascorbic acid content of apple juice. Tiwari et al. (2009) found that anthocyanins exhibit a high degree of stability to sonication. These results indicated that the content and stability of bioactive compounds could be improved by ultrasound treatment.

\subsection{Effect of ultrasound treatment on microbes}

Microbial population present in raw vegetables cause food spoilage and even lead to many food borne diseases. Therefore, sterilization technologies are commonly used in the processing of vegetables to ensure food safety. Effect of ultrasound treatment on microbial survival of carrot juice is shown in Table 4 . It was observed that there was a significant reduction $(p<0.05)$ in total plate count of all the samples sonicated for 20, 40 and $60 \mathrm{~min}$ as compared to non-sonicated sample. Additionally, significant decrease $(p<0.05)$ in total yeast and mold counts was observed in all the treatments. A similar result was obtained by Abid et al. (2013) who found that the significant reduction in the microbial load of ultrasound treated apple juice. From the microcosmic point of view, with the increase of ultrasound treatment time, destruction of microbial tissues and cell membrane was more

Table 4. Effect of ultrasound treatment on microbial survival of carrot juice.

\begin{tabular}{ccc}
\hline $\begin{array}{c}\text { Treatment time } \\
(\mathrm{min})\end{array}$ & $\begin{array}{c}\text { Total plate count } \\
(\log \text { CFU/mL) }\end{array}$ & $\begin{array}{c}\text { Total yeast and mold } \\
\text { counts } \\
(\log \text { CFU/mL) }\end{array}$ \\
\hline 0 & $4.22 \pm 0.21^{\mathrm{a}}$ & $3.97 \pm 0.15^{\mathrm{a}}$ \\
20 & $3.71 \pm 0.15^{\mathrm{b}}$ & $3.36 \pm 0.17^{\mathrm{b}}$ \\
40 & $3.45 \pm 0.10^{\mathrm{c}}$ & $3.25 \pm 0.11^{\mathrm{b}}$ \\
60 & $3.23 \pm 0.11^{\mathrm{d}}$ & $3.03 \pm 0.09^{\mathrm{c}}$ \\
\hline
\end{tabular}

Values with different letters in the same column are significantly different $(p<0.05)$. serious by the ultrasound energy (Yamamoto et al., 2015). The longer the ultrasound treatment time was, the more microbes inactivated, which suggested that extending ultrasound treatment time could decrease the microbial load to a greater extent.

\section{Conclusions}

The effect of ultrasound treatment on quality of carrot juice was studied. There was no significant change $(p>0.05)$ in $\mathrm{pH}$ during ultrasound treatment. Electrical conductivity, viscosity and color values gradually increased $(p<0.05)$ with treatment time increase. Total soluble solids, total sugars, total carotenoids and ascorbic acid contents were significantly improved $(p<0.05)$ due to ultrasound treatment. Microbial load of sonicated carrot juice significantly decreased $(p<0.05)$. The results suggest that ultrasound treatment technology could be potentially employed for the processing of carrot juice and could improve its quality and safety.

\section{Acknowledgements}

This work was supported by the International Science \& Technology Cooperation Program of China (No. 2013DFA31450).

\section{References}

Abid, M., Jabbar, S., Wu, T., Hashim, M. M., Hu, B., Lei, S., Zhang, X., \& Zeng, X. (2013). Effect of ultrasound on different quality parameters of apple juice. Ultrasonics Sonochemistry, 20(5), 1182-1187. http:// dx.doi.org/10.1016/j.ultsonch.2013.02.010. PMid:23522904.

Abid, M., Jabbar, S., Wu, T., Hashim, M. M., Hu, B., Lei, S., \& Zeng, X. (2014). Sonication enhances polyphenolic compounds, sugars, carotenoids and mineral elements of apple juice. Ultrasonics Sonochemistry, 21(1), 93-97. http://dx.doi.org/10.1016/j.ultsonch.2013.06.002. PMid:23835397.

Bhat, R., Kamaruddin, N. S., Min-Tze, L., \& Karim, A. A. (2011). Sonication improves kasturi lime (Citrus microcarpa) juice quality. Ultrasonics Sonochemistry, 18(6), 1295-1300. http://dx.doi.org/10.1016/j. ultsonch.2011.04.002. PMid:21550834.

Caminiti, I. M., Noci, F., Muñoz, A., Whyte, P., Morgan, D. J., Cronin, D. A., \& Lyng, J. G. (2011). Impact of selected combinations of non-thermal processing technologies on the quality of an apple and cranberry juice blend. Food Chemistry, 124(4), 1387-1392. http:// dx.doi.org/10.1016/j.foodchem.2010.07.096.

Cheok, C. Y., Chin, N. L., Yusof, Y. A., Talib, R. A., \& Law, C. L. (2013). Optimization of total monomeric anthocyanin (TMA) and total phenolic content (TPC) extractions from mangosteen (Garcinia mangostana Linn.) hull using ultrasonic treatments. Industrial Crops and Products, 50, 1-7. http://dx.doi.org/10.1016/j.indcrop.2013.07.024.

Cuesta, G., Suarez, N., Bessio, M. I., Ferreira, F., \& Massaldi, H. (2003). Quantitative determination of pneumococcal capsular polysaccharide serotype 14 using a modification of phenol-sulfuric acid method. Journal of Microbiological Methods, 52(1), 69-73. http://dx.doi. org/10.1016/S0167-7012(02)00151-3. PMid:12401228.

Demir, N., Acar, J., \& Bahçeci, K. S. (2004). Effects of storage on quality of carrot juices produced with lacto fermentation and acidification. European Food Research and Technology, 218(5), 465-468. http:// dx.doi.org/10.1007/s00217-004-0883-8.

Di Giacomo, G., \& Taglieri, L. (2009). A new high-yield process for the industrial production of carrot juice. Food and Bioprocess Technology, 2(4), 441-446. http://dx.doi.org/10.1007/s11947-009-0207-x. 
Fonteles, T. V., Costa, M. G. M., Jesus, A. L. T., Miranda, M. R. A., Fernandes, F. A. N., \& Rodrigues, S. (2012). Power ultrasound processing of cantaloupe melon juice: Effects on quality parameters. Food Research International, 48(1), 41-48. http://dx.doi.org/10.1016/j. foodres.2012.02.013.

Gómez, P. L., Welti-Chanes, J., \& Alzamora, S. M. (2011). Hurdle technology in fruit processing. Annual Review of Food Science and Technology, 2(1), 447-465. http://dx.doi.org/10.1146/annurevfood-022510-133619. PMid:22129391.

Lee, H. S., \& Coates, G. A. (1999). Thermal pasteurization effects on colour of red grape fruit juices. Journal of Food Science, 64(4), 663666. http://dx.doi.org/10.1111/j.1365-2621.1999.tb15106.x.

Liao, H., Sun, Y., Ni, Y., Liao, X., Hu, X., Wu, Z., \& Chen, F. (2007). The effect of enzymatic mash treatment, pressing, centrifugation, homogenization, deaeration, sterilization and storage on carrot juice. Journal of Food Process Engineering, 30(4), 421-435. http:// dx.doi.org/10.1111/j.1745-4530.2007.00118.x.

Potter, A. S., Foroudi, S., Stamatikos, A., Patil, B. S., \& Deyhim, F. (2011). Drinking carrot juice increases total antioxidant status and decreases lipid peroxidation in adults. Nutrition Journal, 10(1), 96. http://dx.doi.org/10.1186/1475-2891-10-96. PMid:21943297.

Suárez-Jacobo, A., Rüfer, C. E., Gervilla, R., Guamis, B., Roig-Sagués, A. X., \& Saldo, J. (2011). Influence of ultra-high pressure homogenisation on antioxidant capacity, polyphenol and vitamin content of clear apple juice. Food Chemistry, 127(2), 447-454. http://dx.doi.org/10.1016/j. foodchem.2010.12.152. PMid:23140685.
Tiwari, B. K., Muthukumarappan, K., O’Donnell, C. P., \& Cullen, P. J. (2008). Colour degradation and quality parameters of sonicated orange juice using response surface methodology. LWT - Food Science and Technology, 41(10), 1876-1883. http://dx.doi.org/10.1016/j. lwt.2007.11.016.

Tiwari, B. K., O’Donnell, C. P., \& Cullen, P. J. (2009). Effect of sonication on retention of anthocyanins in blackberry juice. Journal of Food Engineering, 93(2), 166-171. http://dx.doi.org/10.1016/j. jfoodeng.2009.01.027.

Wang, H., Hu, X., Chen, F., Wu, J., Zhang, Z., Liao, X., \& Wang, Z. (2006). Kinetic analysis of non-enzymatic browning in carrot juice concentrate during storage. European Food Research and Technology, 223(2), 282-289. http://dx.doi.org/10.1007/s00217-005-0202-z.

Wu, J., Gamage, T. V., Vilkhu, K. S., Simons, L. K., \& Mawson, R. (2008). Effect of thermosonication on quality improvement of tomato juice. Innovative Food Science \& Emerging Technologies, 9(2), 186-195. http://dx.doi.org/10.1016/j.ifset.2007.07.007.

Yamamoto, K., King, P. M., Wu, X., Mason, T. J., \& Joyce, E. M. (2015). Effect of ultrasonic frequency and power on the disruption of algal cells. Ultrasonics Sonochemistry, 24, 165-171. http://dx.doi. org/10.1016/j.ultsonch.2014.11.002. PMid:25465879.

Zou, Y., Xie, C., Fan, G., Gu, Z., \& Han, Y. (2010). Optimization of ultrasound-assisted extraction of melanin from Auricularia auricula fruit bodies. Innovative Food Science \& Emerging Technologies, 11(4), 611-615. http://dx.doi.org/10.1016/j.ifset.2010.07.002. 